\title{
US looks to German model
}

\section{Bonn}

IN a search for a solution to the estimated 32 million people lacking medical coverage in the United States, supporters of a major overhaul of the US health care delivery system are shifting their sights away from the government-run Canadian system towards the more market-orientated German system.

US health policy analysts and politicians have begun to visit Germany to study how the 108-year-old German scheme, first established by Bismarck, provides highquality medical care to all citizens while avoiding medical inflation. Members of the US House of Representatives Ways and Means Committee, for instance, are considering a trip to examine Germany as a possible model for reform.

At the same time, numerous reports extolling the virtues of the German system have begun to appear in US academic journals and the press. Observers from across the US ideological spectrum say that Germany's example may be more pertinent than Canada's or Britain's because of US anxieties over government control and tax financing.

The quest for a new US health care strategy is particularly pressing because public sentiment for reform of the health care delivery system is at unprecedented levels. A 1990 Conference Board poll found that Americans are more concerned about medical costs than about crime, pollution, AIDS, unemployment or homelessness.

US budget director Richard Darman startled many when he told Congress in April that US corporations will pay more for health insurance this year than they make in total profits. Not surprisingly, many large businesses, including Chrysler Corporation, have joined labour unions in calling for major reforms.

The missing catalyst, many observers say, is a significant show of support from the Bush Administration.

Meanwhile, US economists fret about the growing share health care takes from the gross national product (GNP). In the past decade, health spending outpaced overall economic growth by 33 per cent, rising from 9.3 per cent of GNP in 1980 to 12.2 per cent last year, or $\$ 756,000$ million. Some economists fear that, left uncorrected, health costs could consume 25 per cent of the US economy by 2010 . Spending on health care stood at $\$ 2,354$ per capita in 1989 .

But how should a US national health care system be structured? The years of debate over importing the more-or-less socialist Canadian system southwards were just a "silly diversion", says Princeton health economist Uwe Reinhardt. Instead, he predicts, the United States "will eventually stumble" towards a German-like system of controlled markets, but retaining a strong emphasis on private physicians and employer-financed health insurance.
Germany certainly avoids many of the problems that dog the US health care system. Health care's share of the former West Germany's GNP has hovered around 8.5 per cent since the mid-1970s, and even declined from a peak of 8.9 per cent in 1988 to 8.2 per cent in 1989. At DM1,838 $(\$ 1,232)$ per capita, Germany spends half what the United States does, but has lower infant mortality (tenth versus twenty-fourth among industrialized nations, according to the World Health Organization) and matches average US life expectancy ( 75 years).

Germany has achieved cost control in the face of significant demographic odds. Fifteen per cent of the population is over 65 , compared with 12 per cent in the United States. The doctor-to-patient ratio is the world's highest, and some 20 per cent higher than in the United States. Germans average 11 visits to a physician a year, compared with four in the United States. Hospitalization rates are 44 per cent higher, hospital stays are twice as long and the number of hospital beds per capita is double that in the United States.

What is attractive to US policy-makers is the federal republic's blend of structural elements familiar to US patients - privately administered insurance plans, nearly free choice of physicians and hospitals and virtually immediate access to all services, including high-technology procedures. Both systems are funded by employer contributions, although German workers pay 50 per cent of the premium.

Germany's main strategy is to set limits on overall spending by parliamentary edict, leaving nearly all the operational details to hospitals, physicians and insurers. This "steering" role, says Professor Michael Arnold of the University of Tübingen, insulates the government from the pressures applied to bodies that act as direct payers, such as the Canadian provinces and the US Medicare and Medicaid systems.

Much of the new attention on Germany is focused on the formal price-fixing mechanisms for physician fees and hospital rates. US physicians are particularly intrigued by the negotiations conducted by insurers and regional "doctors' payment organizations", which have legal authority to bargain over fee increases. Such collusion over fees would be illegal under US anti-monopoly rules, although Senate majority leader George Mitchell (Democrat, Maine) is said to be drawing up a proposal that would exempt health care providers.

Since 1986, rises in German physician fees have been directly tied to the average worker's wage fluctuations, while US fees have risen without controls. "To provide first-dollar coverage as we do, you need a fee system for physicians and binding negotiations," says J.-Matthias Graf von der Schulenburg, an economist at the University of Hannover. "If you don't, you'll always have doctors charging more."

Although German physicians earn significantly less than US colleagues, due in part to the fee limits, they have retained a relatively high economic position in society. The average pretax income for German physicians is DM160,000 (\$107,200), compared with $\$ 155,800$ in the United States. German physicians earn four times the average worker's wage - down from six times in 1983 - while US physicians make 6.7 times more than the average worker.

Because of their potential impact on income, expenditure limits were fought fiercely by the American Medical Association (AMA) when proposed in Congress two years ago, but organized medicine now seems more receptive. The AMA has campaigned vigorously against any movement towards a Canadian- or British-style system.

The economic pressure of technological advances in medicine is as evident in Germany as elsewhere, although strict government control over spending on expensive equipment has improved efficiency, German economists say. Nevertheless, physicians exploit the payment system for additional fees by practising what some call "machine medicine".

As in the United States, rises in payments for technical procedures have outpaced those for cognitive services, providing physicians with an incentive to run more tests. As a result, the typical German generalist has an array of money-generating devices in the office that would impress US physicians. Most have ultrasound scanners, sophisticated blood analysers and X-ray equipment.

The German system also achieves significant efficiencies by keeping administrative costs low. For instance, German physicians maintain only one insurance form per patient per quarter, whereas each US physician visit generates an average of 11 pieces of paper.

As bright as the German system may appear in the United States, significant problems lie ahead. "We have too many doctors to employ at a reasonable price," says Peter Rosenberg, a federal health economist in Germany, where an estimated 6,400 physicians are unemployed. Germany graduates as many physicians each year as does the United States and there are constitutional protections guaranteeing career choice that inhibit efforts to limit medical school admissions.

Looming even larger are the possible effects of unification. The 1990 treaty eliminating the frontier essentially called for a wholesale replacement of the former East German socialized system with the West's entrepreneurial one. German officials have estimated it will take as much as DM105,000 million ( $\$ 70,000$ million) to remake the east according to western standards.

Joe R. Neel

Joe R. Neel, a reporter in the Washington bureau of Physician's Weekly, was recently in Germany. 